\title{
DESIGNING A PLAN FOR KEEPING A CONFERENCE IN COVID-19 CONTEXT
}

\author{
Irina-Miruna RADU \\ Bucharest University of Economic Studies, Bucharest, Romania \\ miruna.radu@outlook.com
}

\begin{abstract}
The current social context, where we are facing problems like COVID-19 and climate changes, has created an environment where humans have to be innovative and find new ways to continue their lives showing respect for the rules, for the other people's lives and for the planet Earth. This paper seeks to advance the understanding of designing a virtual conference through identifying advantages and challenges and to provide a draft plan for organizing a conference, a plan using tools available on the market. The researched problem was approached via a two-step selection process of the most relevant studies in achieving the objectives. As a result, the paper highlights the strengths that can be used to plan a successful virtual conference, only if the challenges are overcome. It also offers a schema for a virtual conference. As a conclusion, this article takes steps in identifying and preparing a universal plan to support the community in keeping events like conferences in the actual context with technologies available on the market.
\end{abstract}

Keywords: advantages of virtual conferences, challenges of virtual conferences, virtual conference

\section{INTRODUCTION}

The concept of virtual conference it is not a new one. In 1992 Bangkok Project (Anderson \& Mason, 1993) was the first international Internet supported conference. The interaction between participants was on email and was structured in six interactive sessions over a three-week period.

So as the person who made possible the Bangkok Project remarked (ANDERSON, 1996) the first virtual conferences were limited by software and bandwidth and constrained to their technological context. There are almost 30 years from then and at this point the evolution of technology and studies on virtual empathy can give us all the information we need to create a virtual conference that can overcome challenges.

And the actual social context of COVID-19 even forces us to concentrate our powers in investigating what is already on the market. Finding fast solutions, it will let us continue our life from our safety of our home, while being able to not restrict some of our plans.

This paper proposes to structure a rough design for a virtual conference using its advantages to make it more appealing to possible participants, while trying to overcome the challenges. For being able to achieve this goal the main objectives of this research are: 
- $\quad$ Conduct an in-depth study of the existing information about virtual conferences

Articles relevant to topic are searched in the different scientific databases and only the significant ones are furthermore analyzed to better understand the what, how, do's and don'ts of virtual conferences.

- $\quad$ Find advantages and challenges of virtual conferences

From the selected articles it is important to identify the opportunities a virtual conference grants to this kind of event, but also it is necessary to keep an eye on the drawback and see them as challenges that have to be overcome.

- $\quad$ Develop a plan for a virtual conference within existing technologies

With the information at hand it is time to draft a plan for the conference, a schedule for different activities.

\section{LITERATURE REVIEW}

Many studies regarding virtual conferences have been conducted and in our social context where COVID19 makes us experiment social distancing it is important to centralize the advantages and disadvantages to be able to design and organize a nice virtual conference.

Lots of the studies are clustered around architecture and design. In Kasser (2000), the author describes the development of an asynchronous virtual conference, highlighting the advantages and disadvantages and the lessons learned. Shih et al. (2001) propose a virtual conference system based on mobile communication in order to improve the real-time transfer of data. Sempere (2011) presents a case study of a virtual conference design that was adjust based on feedback, to improve the nature of interactions between participants. The paper also outlines some design principles learned, that can be applied generally to make the collaborative experience more effective.

Some of the papers published until now are putting an accent on certain parts of the structure of a virtual conference. As Rogers et al. (2018) mentioned an essential part of a good conference is the networking and cultural enrichment aspect. Taking this into consideration they propose a concept of a Virtual Cocktail Party, a tool to integrate into a virtual conference to be able to obtain a more sociable friendly environment. Jones (2000) also shares some stories from the field of on-line conferences on how to improve the collaborative aspect, putting also an accent on the lessons learned. This provides a good overview of the difficulties of virtual empathy and networking and how they can be overcome.

\section{METHODOLOGY}

In order to study the currently available virtual conferences information, a literature review process in two steps was conducted. The first step involved identifying the relevant sources based on certain keywords, 
Radu, I-M.

DESIGNING A PLAN FOR KEEPING A CONFERENCE IN COVID-19 CONTEXT

while the second step involved interpreting and evaluating the relevance of the selected articles to this study.

The review process was conducted in the beginning of 2020. In the first step, databases like Google Scholar, Science Direct, ACM Digital Library and others were analyzed for identifying relevant studies. For this selection where chosen publications that contained with keywords like "virtual conference", "advantages of virtual conferences", "challenges of virtual conferences", "tools for virtual conferences" in their title. In the next step, the abstracts were reviewed and the articles that were not relevant were rejected. After, all the remaining articles were read, the advantages and challenges where outlined to draw the attention the most common ones.

\section{RESULTS}

In Table 1 is presented an overview of the findings. Every advantage and challenge is presented through the relation with the articles it was mentioned in. For example, it can be easily seen that reduction of costs is a clear advantage of virtual conferences as it is mentioned in most of the studies, while technological issues are recurrent challenges through the publications.

TABLE 1. ADVANTAGES AND CHALLENGES OF VIRTUAL CONFERENCES

\begin{tabular}{|c|c|c|c|}
\hline Advantages/Challenges & Category & Description & Citation \\
\hline \multirow[t]{2}{*}{ Advantages } & $\begin{array}{l}\text { Reduce } \\
\text { pollution }\end{array}$ & $\begin{array}{l}\text { Travel emissions, energy and } \\
\text { waste }\end{array}$ & $\begin{array}{l}\text { (Diethart, } \\
\text { Zimmermann, \& } \\
\text { Mulà, 2020); } \\
\text { (Dean, } \\
\text { Apperley, \& } \\
\text { Rogers, 2014); } \\
\text { (Suravajhala, } \\
\text { Bizzaro, } \\
\text { Varadwaj, } \\
\text { Gupta, \& Singh, } \\
\text { 2010); (Welch, } \\
\text { Ray, Melendez, } \\
\text { Fare, \& Leach, } \\
\text { 2010) }\end{array}$ \\
\hline & Inclusive & Space is flexible. People from all & (Diethart, \\
\hline
\end{tabular}


Radu, I-M.

DESIGNING A PLAN FOR KEEPING A CONFERENCE IN COVID-19 CONTEXT

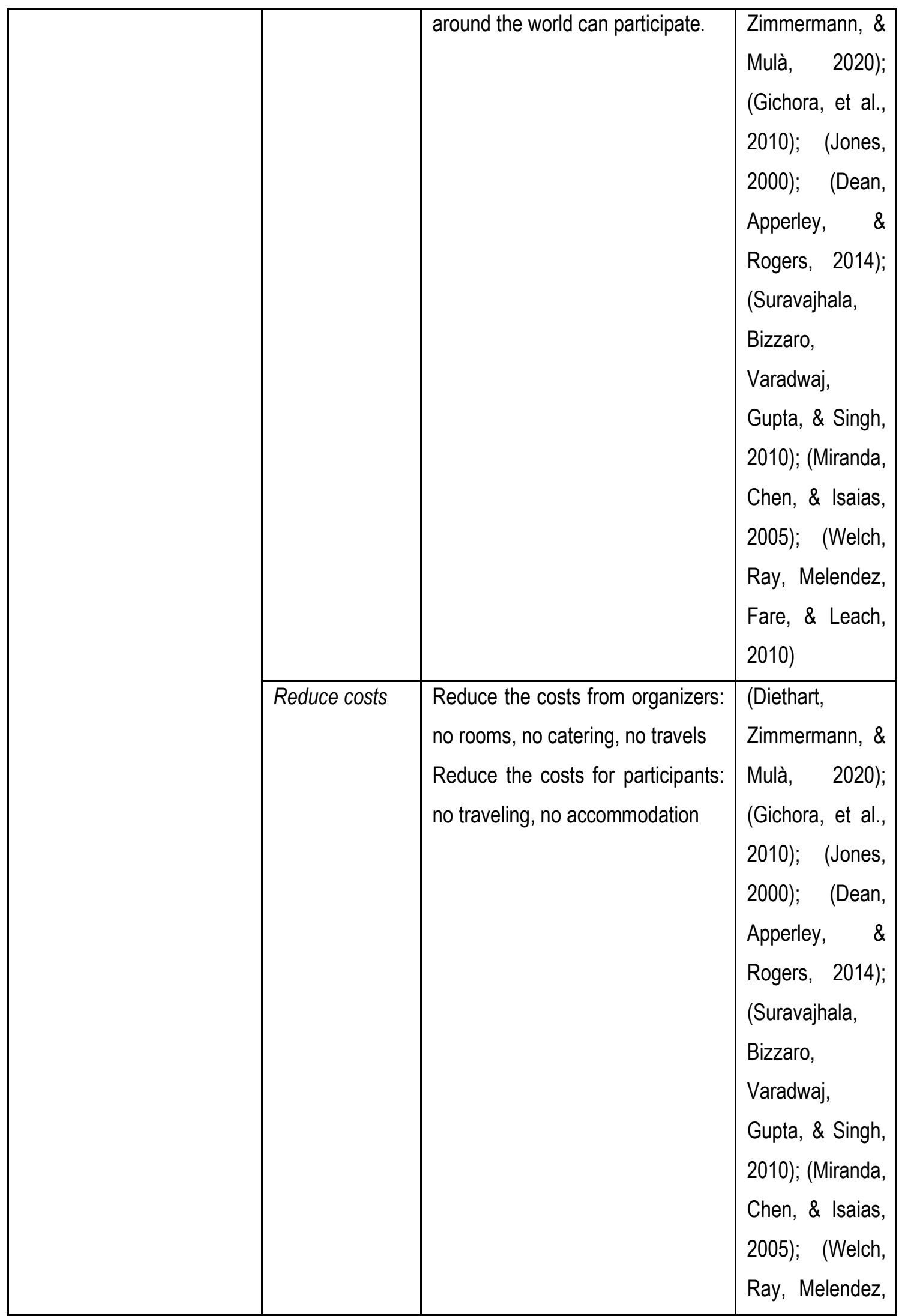


Radu, I-M.

DESIGNING A PLAN FOR KEEPING A CONFERENCE IN COVID-19 CONTEXT

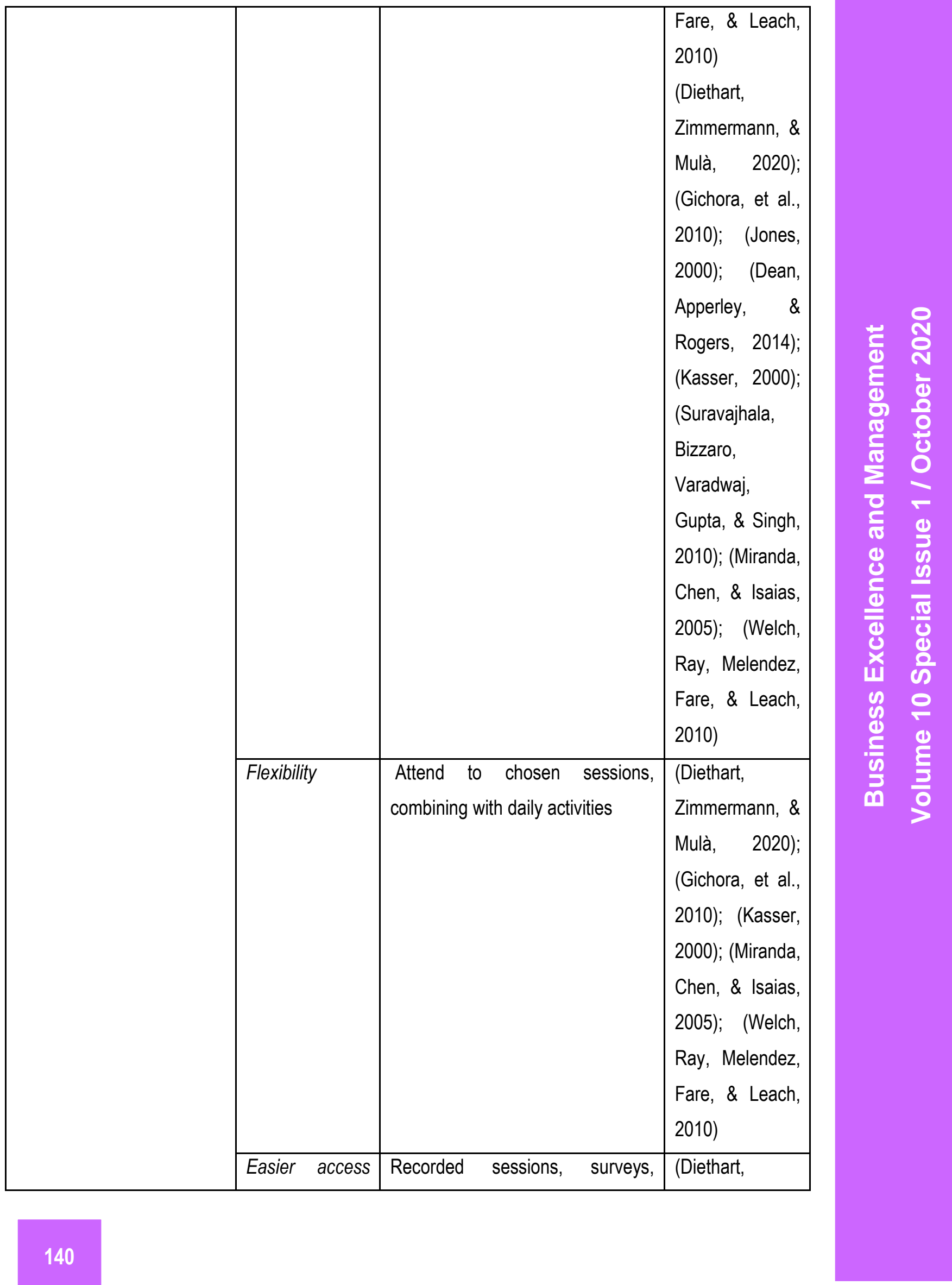


Radu, I-M.

DESIGNING A PLAN FOR KEEPING A CONFERENCE IN COVID-19 CONTEXT

\begin{tabular}{|c|c|c|c|}
\hline & $\begin{array}{l}\text { to the } \\
\text { information }\end{array}$ & forums & $\begin{array}{l}\text { Zimmermann, \& } \\
\text { Mulà, 2020); } \\
\text { (Jones, 2000); } \\
\text { (Kasser, 2000); } \\
\text { (Suravajhala, } \\
\text { Bizzaro, } \\
\text { Varadwaj, } \\
\text { Gupta, \& Singh, } \\
\text { 2010); (Miranda, } \\
\text { Chen, \& Isaias, } \\
\text { 2005) }\end{array}$ \\
\hline & $\begin{array}{l}\text { Reduce } \\
\text { complexity }\end{array}$ & $\begin{array}{l}\text { Not having to book travel, } \\
\text { accommodation }\end{array}$ & $\begin{array}{l}\text { (Diethart, } \\
\text { Zimmermann, \& } \\
\text { Mulà, 2020); } \\
\text { (Gichora, et al., } \\
\text { 2010); (Jones, } \\
\text { 2000); (Miranda, } \\
\text { Chen, \& Isaias, } \\
\text { 2005); (Welch, } \\
\text { Ray, Melendez, } \\
\text { Fare, \& Leach, } \\
\text { 2010) }\end{array}$ \\
\hline Challenges & $\begin{array}{l}\text { Networking, } \\
\text { Interactions }\end{array}$ & $\begin{array}{l}\text { A face-to-face environment leaves } \\
\text { space for unplanned spontaneous } \\
\text { social interactions, getting to know } \\
\text { new places and new cultures by } \\
\text { experiment. }\end{array}$ & $\begin{array}{l}\text { (Diethart, } \\
\text { Zimmermann, \& } \\
\text { Mulà, 2020); } \\
\text { (Gichora, et al., } \\
\text { 2010); (Jones, } \\
\text { 2000); (Rogers, } \\
\text { Masoodian, \& } \\
\text { Apperley, 2018); } \\
\text { (Dean, } \\
\text { Apperley, \& } \\
\text { Rogers, 2014); }\end{array}$ \\
\hline
\end{tabular}


Radu, I-M.

DESIGNING A PLAN FOR KEEPING A CONFERENCE IN COVID-19 CONTEXT

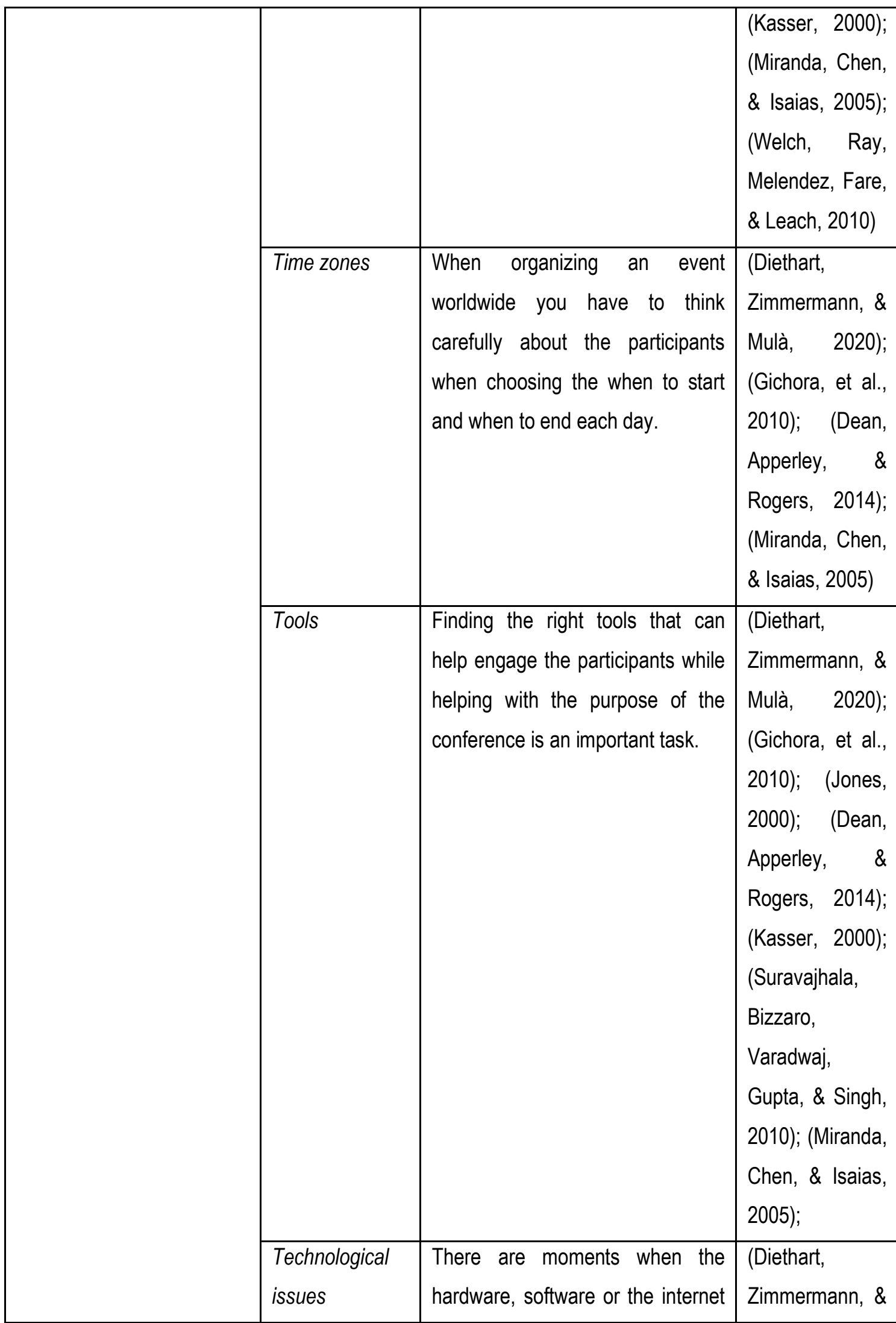


Radu, I-M.

DESIGNING A PLAN FOR KEEPING A CONFERENCE IN COVID-19 CONTEXT

\begin{tabular}{|l|l|l|}
\hline & connection can go wrong. & Mulà, 2020); \\
& (Gichora, et al., \\
& 2010); (Jones, \\
& 2000); (Kasser, \\
& 2000); \\
& (Suravajhala, \\
& Bizzaro, \\
& Varadwaj, \\
& Gupta, \& Singh, \\
& 2010); (Miranda, \\
& Chen, \& Isaias, \\
& 2005); (Welch, \\
& Ray, Melendez, \\
& Fare, \& Leach, \\
& 2010) \\
\hline
\end{tabular}

Source: Created by author, based on literature review

\section{OVERCOME THE CHALLENGES}

To overcome the challenge of networking and lack of social aspect form the virtual conferences Rogers et al. (2018) propose a virtual cocktail party prototype: creating a game-like environment where participants can listen to other people's talks and get into conversation at any time like in real events. The paper (Dean, Apperley, \& Rogers, 2014) analyzed using SecondLife a game like conference trying to propose a prototype to fix problems like: lack of identity, lack of real time gesture feedback, hard movement through the conference. However, in the end of the study they find it difficult to extend their solution at great scale. Also, for the problem with the interactions with each other Kasser (2000) proposed using live sessions of QA.

For the technical difficulties Miranda et al. (2005) propose having a tech person ready to help with any technical related problem. To avoid problems with the tools Welch et al. (2010) propose sending a script to the participants that will install all the needed software. To avoid the problems with the bandwidth and conference interruption Gichora et al. (2010) advice to pre-recorded presentations which can be used when in need. 


\section{PLAN FOR A VIRTUAL CONFERENCE}

The plan designed in this section is for a start-up conference. The plan for the conference before COVID-19 was to have some stands where people from the start ups can have some short presentations and some giveaways. They could also interact with the early-adopters and respond to their questions. After, a live session of presentation was expected.

The context made the constraint to transform the planed event into a virtual one. Analyzing all the new information regarding virtual conferences the new plan is structured different. The conference will be spited into two parts:

\section{- The virtual fair}

The first part will be structured as a place where attendants can find information regarding the start-ups. Each one of the start-up will have a virtual space where they can display a short presentation, some interesting facts. Also here they will have a link to their proof of concept which can be tried in real time by the crowd. A board for feedback and communication will be there to make the session more interactive. To avoid technical problems regarding installing special applications, the virtual fair will be hosted online and for avoiding problems with the presentation this will be prerecorded. This will help also with the time zone, the virtual stands being available for a longer time so all the participants can take a look at them. A designated person form the organization team will be available to help at any time with any technical problem.

Tools that can be used for creating a virtual fair with game like interaction are vFairs (vfairs), voxexpo (Voxexpo) or hexafair (Hexafair). Beside this the virtual fair can be created from scratch as a web application or maybe as a simple website.

\section{- A Q\&A live session}

To avoid the challenge of networking at this virtual event there will be a live web-based session of questions and answers where each start-up will meet with the people and answer the questions. The time zone of the attendants will be taken into consideration when deciding the time of the session.

As tools for this session there are multiple choices that allow users with no accounts to attend to web meetings like: Microsoft Teams, JoinME, Zoom.

\section{CONCLUSIONS}

Transforming a conference from a face-to-face one into a virtual one can be an easy thing to achieve when understanding the big picture. Virtual conferences offer a series of advantages that can help with 
increasing the numbers of participants, but only when the challenges are taken into consideration. Analyzing these aspects, the current paper proposes a virtual conference split into two parts that satisfy different needs like networking, error free and time zone appropriate. The first part includes the idea of having a virtual fair through different technical solutions, a place where the attendee can easily have access to the information that is needed when is needed. The second part it is concentrated around the idea of having a live session of questions and answers to help with the direct social interaction aspect that sometimes is missing in an online event.

\section{ACKNOWLEDGEMENTS}

This paper was co-financed from the Human Capital Operational Program 2014-2020, project number POCU / 380/6/13/125245 no. 36482 / 23.05.2019 "Excellence in interdisciplinary PhD and post-PhD research, career alternatives through entrepreneurial initiative (EXCIA)", coordinator The Bucharest University of Economic Studies".

\section{REFERENCES}

Anderson, T. D. (1996). The Virtual Conference: Extending Professional Education in Cyberspace. International Jl. of Educational Telecommunications. 3(2): 121-135

Anderson, T., \& Mason, R. (1993). International computer conferencing for professional development: The Bangkok Project. The American Journal of Distance Education, 7(2): 5-18

Dean, J., Apperley, M., \& Rogers, B. (2014). Refining personal and social presence in virtual meetings. AUIC '14: Proceedings of the Fifteenth Australasian User Interface Conference, 150. Auckland

Diethart, M., Zimmermann, A. B., \& Mulà, I. (2020). Guidelines for Virtual Conferencing - inspired by the COPERNICUS Alliance Online Conference 2019. Centre for Development and Environment (CDE), University of Bern and COPERNICUS Alliance -European Network on Higher Education for Sustainable Development

Gichora, N. N., Fatumo, S. A., Ngara, M. V., Chelbat, N., Ramdayal, K., Opap, K. B., et al. (2010). Ten Simple Rules for Organizing a Virtual Conference-Anywhere. PLOS Computational Biology, 6(2): $1-4$

Hexafair. (n.d.). Retrieved March 2020, from https://www.hexafair.com/

Jones, M. L. (2000). Collaborative Virtual Conferences: Using Exemplars to Shape Future Research Questions. CVE '00: Proceedings of the third international conference on Collaborative virtual environments, 19-27

Kasser, J. (2000). A Web Based Asynchronous Virtual Conference-A Case Study. The INCOSE-MidAtlantic Regional Conference.

Miranda, P., Chen, N.-S., \& Isaias, P. (2005). DESIGN, IMPLEMENTATION AND EVALUATION OF A VIRTUAL CONFERENCE. IADIS International Conference e-Society 
Rogers, B., Masoodian, M., \& Apperley, M. D. (2018). A Virtual Cocktail Party: Supporting Informal Social Interactions In A Virtual Conference. AVI '18: Proceedings of the 2018 International Conference on Advanced Visual Interfaces. Grosseto

Sempere, A. (2011). Architecture and design for virtual conferences: A case study. Future Internet, 3(3), 175-184.

Shih, T. K., Huang, J.-Y., Wang, C.-S., \& Hung, J. C. (2001). An Efficient Approach to Holding a Virtual Conference. Proceedings of the National Science Council, Republic of China. 25(6): 352-366

Suravajhala, P. N., Bizzaro, J. W., Varadwaj, P., Gupta, A., \& Singh, T. (2010). Influence of virtual conferences on bioinformatics in India and developing nations. Current science. 98(11): 1428-1429

vfairs. (n.d.). Retrieved March 2020, from https://www.vfairs.com/

Voxexpo. (n.d.). Retrieved March 2020, from http://voxexpo.com/en

Welch, C. J., Ray, S., Melendez, J., Fare, T., \& Leach, M. (2010). Virtual conferences becoming a reality. Nature chemistry. 2(3): 148-152 